\title{
An 80 year record of retreat of the Koettlitz Ice Tongue, McMurdo Sound, Antarctica
}

\author{
AnTHONy J. Gow and John W. Govoni \\ U.S. Army Cold Regions Research and Engineering Laboratory, Hanover, NH 03755, U.S.A.
}

\begin{abstract}
A survey of ice-front changes since 1910-13 shows that the Koettlitz Ice Tongue, located along the western shore of McMurdo Sound, Antarctica, has undergone significant retreat during the past 80 years. The ice front in 1910-13 was located $5 \mathrm{~km}$ in front of the Dailey Islands. 'Ioday, only two of the six Dailey Islands remain connected to the Koettlitz Ice Tongue. The most recent break-out of ice is believed to have occurred in 1979 or 1980 , rcsulting in an cstimatcd loss of $80 \mathrm{~km}^{2}$ of ice. Based on the current position of the ice front, it is estimated that a minimum of $300 \mathrm{~km}^{2}$ of icc has calved off the Koettlitz Ice Tongue during the 80 year period that has elapsed since the ice front was first mapped in 1910-13.
\end{abstract}

\section{INTRODUCTION}

The floating shelf-like tongue of Koettlitz Glacier, located along the western shore of McMurdo Sound, has attracted considerable scientific attention since the days of Scott's expeditions, mainly on account of the fish and marine invertebrates found on its ablating surface Debenham, 1920, 1948, 1961; Swithinbank and others, 1961; Gow and others, 1965). A mechanism of combined basal adfreezing and surface ablation to explain the origin of this unique collection of marine fauna was first hypothesized by Debenham (1920) and subsequently confirmed by the work of Gow and Epstein (1972). Unfortunately, the great bulk of this unique deposit was lost during a major break-out of the ice from the immediate vicinity of the Dailey Islands. This breakout, believed to have occurred in 1979 or 1980 (but not actually observed, resulted in the loss of approximately $80 \mathrm{~km}^{2}$ of ice. At the time this discovery of such an extensive calving of ice was first reported by Gow and others (1981), only the two easternmost of the six Dailey Islands remained connected to the Koettlitz Ice Tongue. Faunal remains are now restricted to this piece of ice; from the tenuous nature of this connection, it appeared that the ice was fated for imminent detachment from the two islands. However, subsequent growth of thick multiyear ice in the embayment created by the 1979 or 1980 ? break-out appears to have stabilized the part of the ice tongue that still remains connected to the two easternmost Dailey Islands as of 1992.

The purpose of this paper is to report evidence of retreat of the Koettlitz Ice Tongue obtained during the past 80 years.

\section{OBSERVATIONS AND DISGUSSION}

Observations of the position of the ice front of the
"Koettlitz Glacier Tongue" made during Scott's British Antarctic Terra Nova Expedition, 1910-13 (Debenham, 1948 ) indicate that it extended $5-6 \mathrm{~km}$ north of the six Dailey Islands as shown in Figure 1. At that time, the Dailey Islands would appear to have served as anchor points for stabilizing the position of the ice front which extended in a southwesterly direction from the Daily

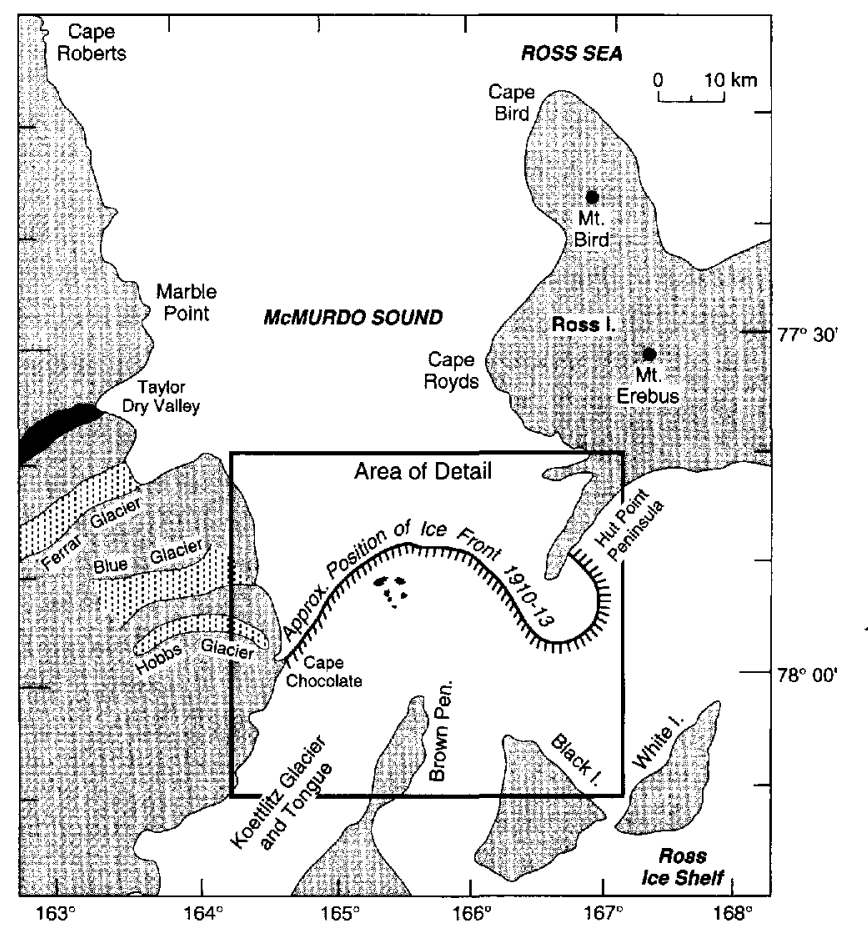

Fig. 1. Map of the McMurdo Sound area showing the location of Koettlitz Glacier and its floating shelf-like longue. Approximate position of the ice front as mapped during the British Antarctic Terra Nova Expedition, 1910-13, is also indicated. 
Islands to the immediate vicinity of Cape Chocolate (see area of detail, Fig. 2) on the western shore of McMurdo Sound. Speden and Brown (1962), utilizing the Terra Nova Expedition map, also indicated the position of the ice front as of 1947 (see Fig. 2). The source of data on which this positioning of the ice front is based is not given. There appears to be no change in ice-edge position in the immediate vicinity of the Dailey Islands. However, east of the Dailey Islands a substantial lenticular-shaped break-out of ice is shown where the Koettlitz. Ice Tongue merges with the McMurdo Ice Shelf.

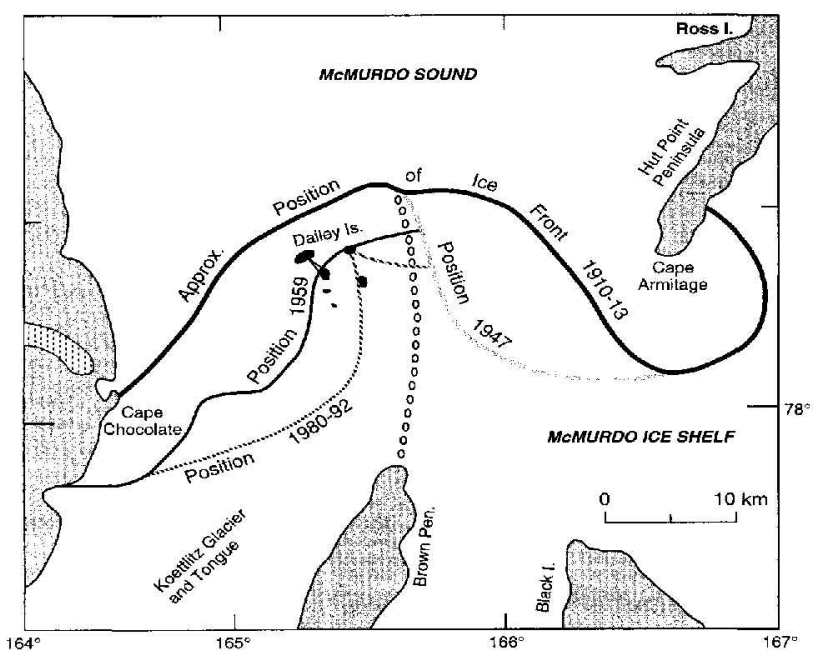

Fig. 2. Area of detail of Foettlitz Glacier and tongue as indicated in Figure 1. Shown are the locations of the six Dailey Islands and the approximale positions of the ice fronts as observed from 1910-13 to 1992. The approximate position of the boundary between the Koellits lie Tongue and the McMurdo Ice Shelf is indicated by the line of open circles.

Photography flown by the U.S. Navy during the International Geophysical Year Program in Antarctica shows significant retreat of the Koettlitz Glacicr Icc Front since Scott's time. A 6 December 1956 aerial photograph, showing retreat back to the Dailey Islands is reproduced in Figure 3. Only the three westernmost islands are featured in this particular photograph but adjacent photographs show that the ice front was still connected to all six Dailey Islands at this time. Additional photography flown by the C.S. Navy in 1959 shows major calving of the ice edge, not only in the vicinity of the westernmost of the Dailey Islands which now retaincd only a very tenuous connection with the ice front (Fig. 4) but also along its western edge and several kilometers south of Cape Chocolatc. Much of this calving likely occurred before 1956, but we do not possess U.S. Navy photographs taken south and west of the Dailey Islands to verify this situation.

The U.S. Geological Survey Ross Island 1:250000 Reconnaissance Map published in 1965 shows all six Dailcy Islands still connected to the Koettlitz Ice Tongue. The ice front is undated but its positioning, especially in the vicinity of the Dailey Islands, conforms closely with the U.S. Navy 1956 aerial photograph, but it is at variance with the 1959 aerial photograph. Furthermore,

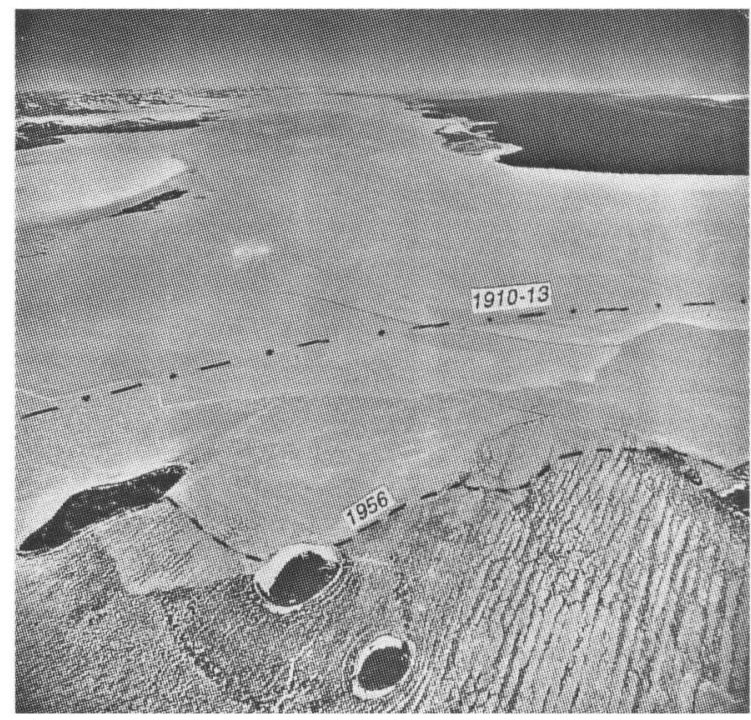

Fig. 3. Aerial photographs showing 1910-1.3 and 1956 ice-front positions relative to the three westemmost Dailer Islands. Photograph, looking north into Mc Murdo Sound, was taken in December 1956 by the U.S. Nazy (TMA 336) for the U.S. Geological Suriey.

while one of the authors (A.J.G.) was conducting field studies of the Koettlitz Ice Tongue in 1964, he observed that the westernmost of the Dailey Islands was no longer connected to the ice front. This detachment, the first indication of actual retreat of the ice cdge from the Dailey Islands, must have occurred after 1959 but before 1964 .

The next source of information on the disposition of the Koettlitz ice edge came via the first Earth Resources Technology Satcllite (ER'IS) that was launched into a near-polar orbit on 23 July 1972. Examination of a 13

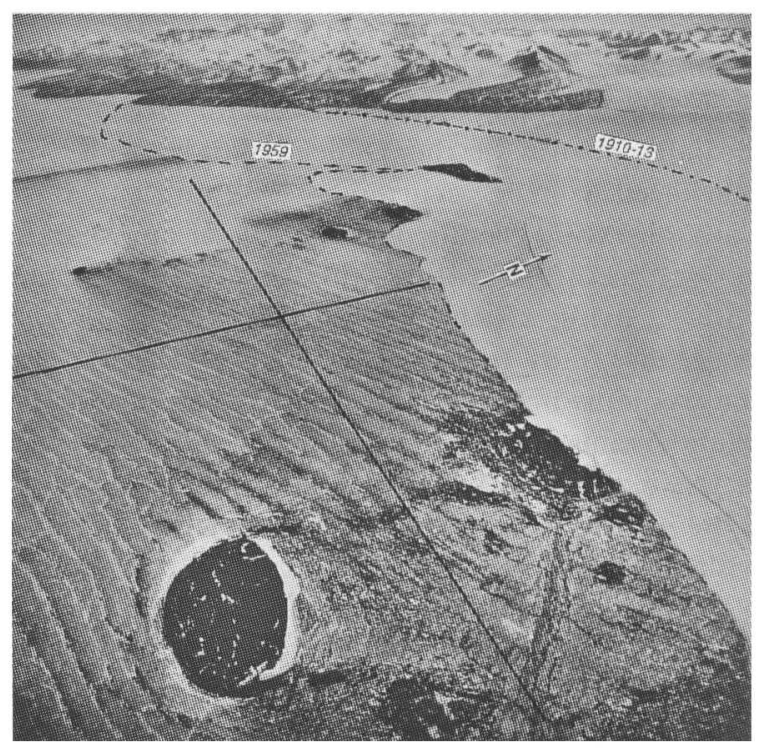

Fig. 4. Aerial pholograph of the six Dailey Islands and the Koettlitz Glacier Tongue showing positions of ice fronts in 1910-13 and 1959. Photograph taken in $1959 \mathrm{by}$ the U.S. Nay (TMA 1278) for the U.S. Geological Survey. The cross-like pattern of lines indicates pasitions of surey lines along which ice-flow velocities (5-10 $\mathrm{ma}^{-1}$ ) were measured during the period 1964-66. 


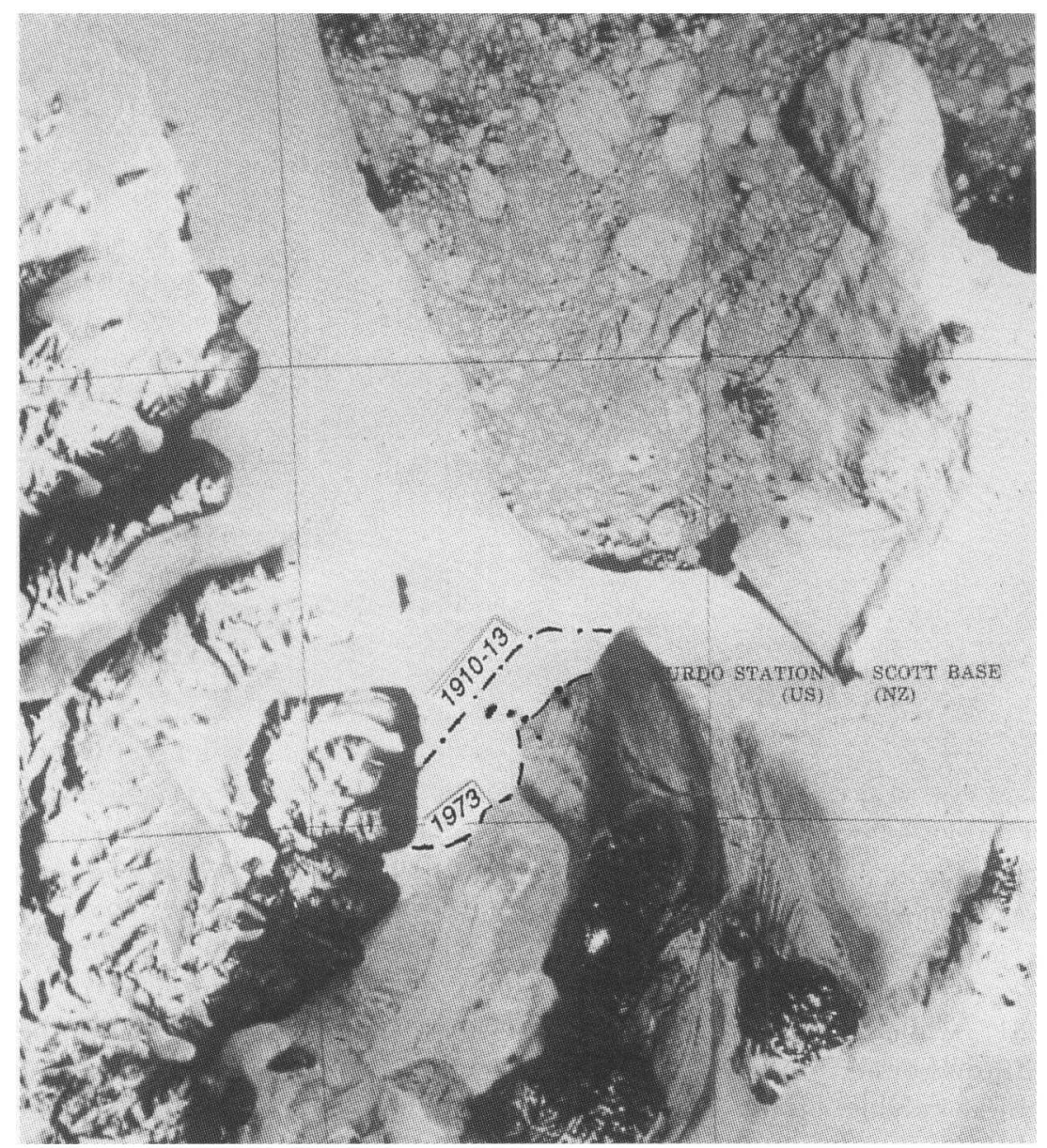

Fig. 5. 13 Jamuary 1973 ERTS pholograph No.81124194335 of the McMurdo Sound region showing approximate pasitions of 1910-13 and 1973 ice fronts in the immediate vicinity and south of the Dailey Istands.

January 1973 ERTS photograph of the McMurdo Sound area (Fig. 5) slows further retreat of the ice front: the second westernmost of the Dailey Islands had now become disconnected and additional loss of ice from the western edge had also occurred. Swithinbank (1973), reporting on his own cxamination of the same ERTS picture, estimated that a retreat of up $103 \mathrm{~km} \mathrm{had}$ occurred in the vicinity of the 1)ailey Islands, based on a comparison with the icc cdgc shown on the 1965 USGS reconnaissance map of the area.

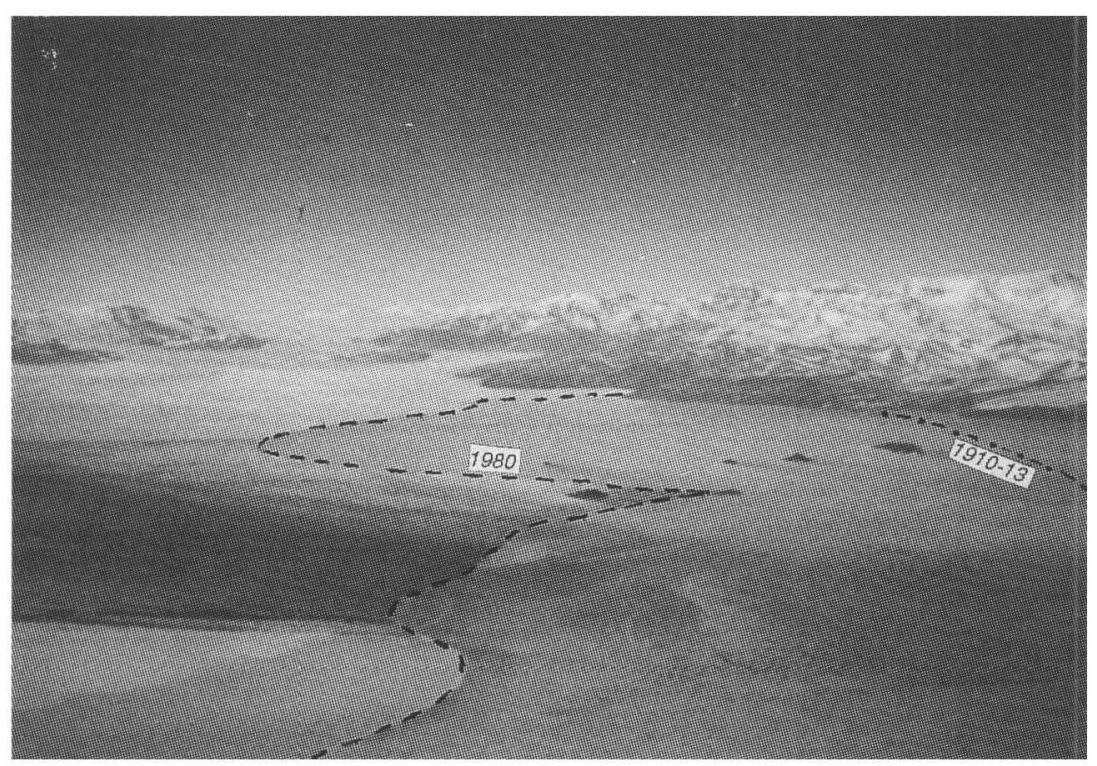

Fig. 6. Aerial photograph taken in November 1980 of the Koettlitz Le Tongue showing the positions of the 1910-13 and 1980 ice fronts in the immediate vicinity and soult of the Dailey Islands. 


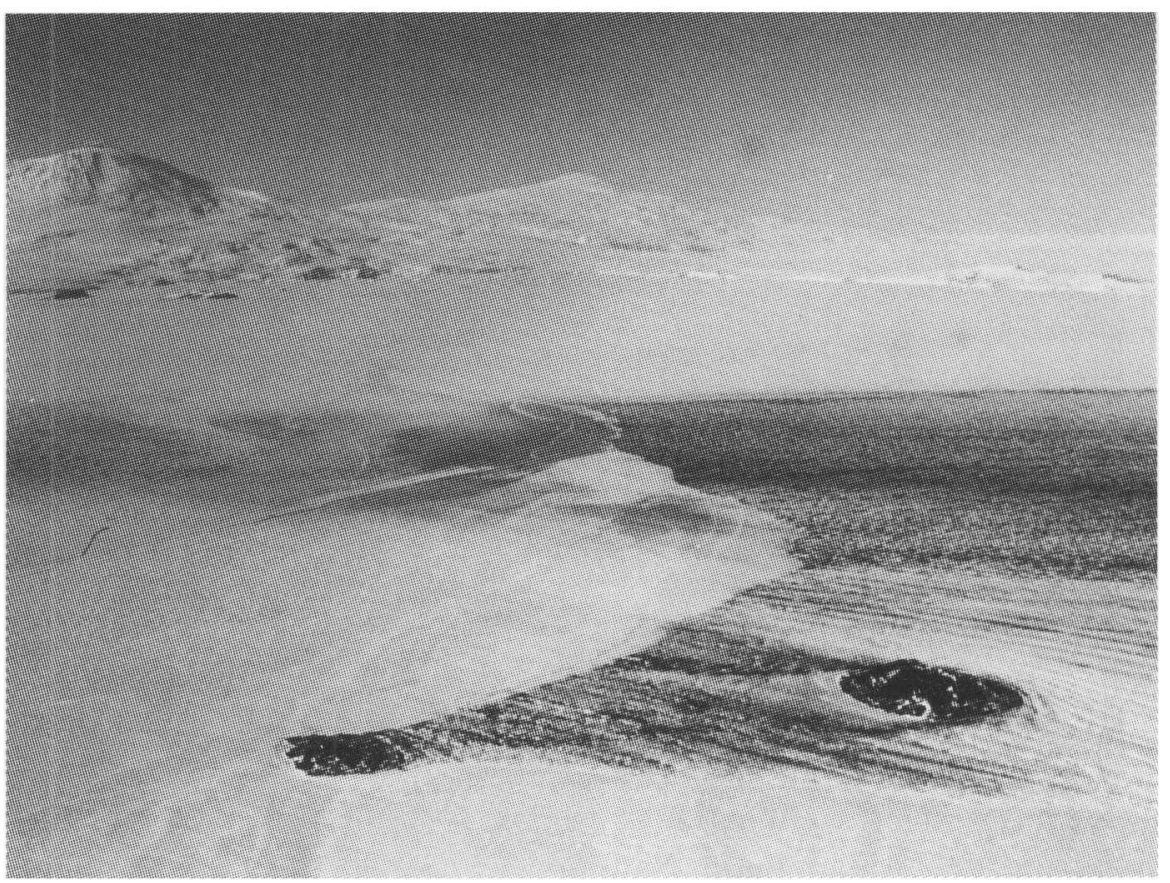

Fig. 7. Aerial photograph taken in November 1980 showing the ice edge looking east of the two easternmost Dailey Islands towards Mount Erebus (top left) and IIut Point Peninsula (middle right).

Gow and others (1981), while carrying out investigations of sea ice in McMurdo Sound in November 1980 , reported a very substantial calving of the ice tongue rearwards of the Dailey Islands. The line of the break-out is indicated in Figure 2 and aerial photographs featuring different aspects of this break-out are shown in Figures 6 , 7 and 8. At that time, only the two easternmost Dailey Islands still remained connected to the Kocttitz Icc Tongue. Faunal remains are restricted to this piece of ice which, from the tenuous nature of its connections to the two islands, seemed destined for imminent brcak-out. However, subsequent growth of thick multi-year ice appears to have stabilized this piece of ice and as of 1992 it still remains attached to the two casternmost
Dailey Islands. The position of the ice front also appears to have remained substantially unchanged since 1980 . From flow rates reported by Gow (1967), of the order 5$10 \mathrm{~m} \mathrm{a}^{-1}$, the ice front has not likely advanced more than $100 \mathrm{~m}$ since 1980 . This last major break-out of ice from the Kocttlitz Ice Tongue must have occurred between 1973 and 1980 , most probably after 1977 when a visit to the Koettlitz Icc Tongue by one of the authors (A.J.G. revealed no significant change in ice-front position from that of 1973. The precise reason for the most recent breakout is not known; it was most likely triggered by a major storm event. The change in the position of the ice front observed in 1980 may be related to the 1979 break-out of thick multi-ycar sea ice along the western shore of

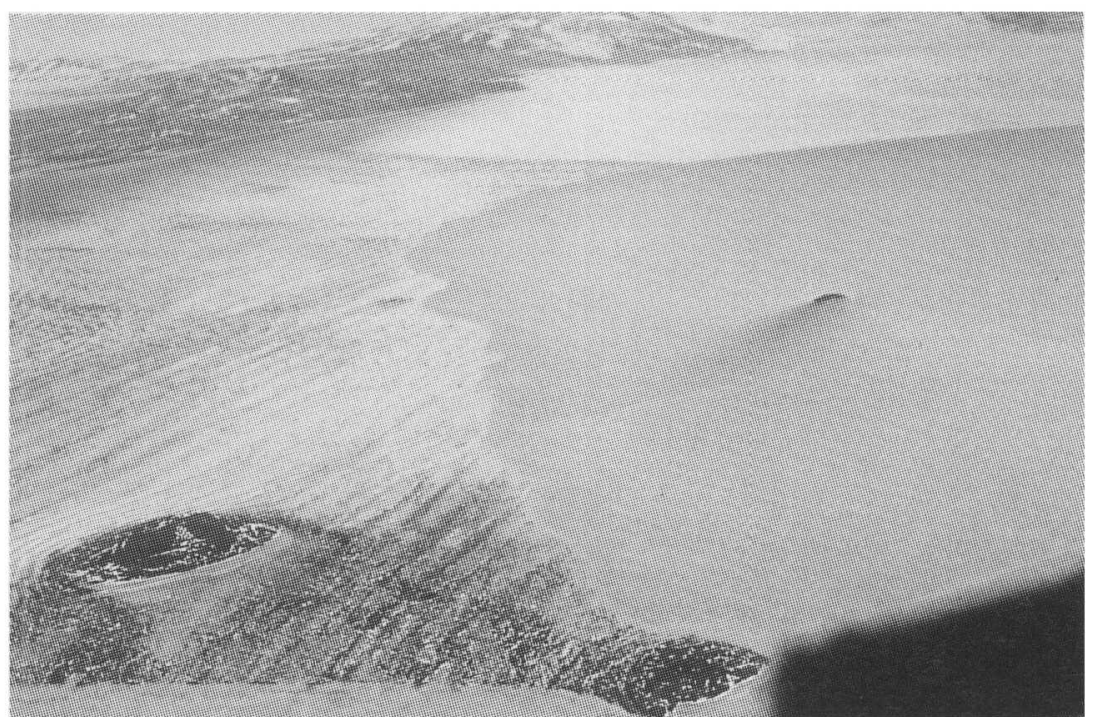

Fig. 8. Aerial photograph taken in November 1980 showing the ice edge looking south and to the rear of the easternmost Dailey Islands. Brown Peninsula is at the top left of the photograph. Koettlitz Glacier is located at the top right. 
McMurdo Sound as reported by Levcnter and Dunbar 1988 or, it may have coincided with a major break-out of the McMurdo Ice Shelf during the period 6 February22 March 1980 (Morey and Kovacs, 1981). According to Morey and Kovacs, this break-out resulted in the loss of $1.6 \mathrm{~km}$ of ice from the front of the McMurdo Ice Shelf. Bascd on a comparison of the current position of the ice front and that mapped in $1910-13$, it is estimated that approximatcly $300 \mathrm{~km}^{2}$ of icc has been lost from the Kocttlitz Ice Tongue during the last 80 years.

\section{CONCLUSIONS}

The Koettlitz Ice Tongue, McMurdo Sound, Antarctica, has undergone significant retreat since it was first mapped during Scott's 1910-13 British Antarctic Terra Nova Expedition. At that time, the ice front extended $5-6 \mathrm{~km}$ north of the Dailey Islands. Utilizing a combination of aerial photographs, satellite pictures and visual observations, it has proven possible to reconstruct the record of ice-edge retreat for the past 80 years. Following the last major break-out, believed to have occurred during 1979 or 1980 but not actually obscrved first-hand, the position of the ice edge appears to have stabilized. Originally connected to all six islands of the Dailey lslands group, the ice tongue now retains connection with only the two easternmost islands. Loss of ice from the Koettlitz Icc Tonguc over the last 80 years is estimated to cxced $300 \mathrm{~km}^{2}$.

\section{REFERENCES}

Debenham, F. 1920. A new mode of transportation by ice: the raised marine muds of South Victoria Land (Antarctica). Quart. 7. Geol Soc., fondon, 75, 51-76.

Debenham, F. 1948. The problem of the great Ross Barrier. Geogr. $\mathcal{J}$., $1124), 196218$.

Debenham, F. 1961. A lish story from the Antarctic. Geogr. Mag., 34(6), $360-368$.

Gow, A.J. 1967. Antarctic glaciological studies. Antarct. 7. U.S., 11(4), $121-122$.

Gow, A.J. and S. Epstein. 1972. On the use of stable isotopes to trace the origins of ice in a floating ice tongue. $J$. Ceophys. Res., 77 33$), 6552-6557$.

Gow, A.J., W.F. Wecks, G. Hendrickson and R. Rowland. 1965. On the mode of uplift of the fish and fossiliferous moraines of the McMurdo Ice Shelf, Antarctica. CRREL Res. Rep. 173.

Gow, A.J., W.F. Weeks, J. W. Govoni and S. F. Acklcy. 1981. Physical and structural characteristics of sca ice in McMurdo Sound. Antart. J. U.S., 16 5$), 94-95$

Leventer. A. and R.B. Dumbar. 1988. Recent diatom record of McMurdo Sound, Antarctica: implications for history of sca ico cxtent. Paleoceanography, 3(3), 259-274.

Morey, R. M. and A. Kovacs. 1981. High-resolution impulse radar measurements for detecting sea ice and current alignment under the Ross loc Shelf. Antarct. 7. V.S., 16 (3), 96-97.

Speden, I. G. and 1. A. Brown. 1962. Fossiliferous Quaternary marine deposits in the McMurdo Sound region, Antarctica. $N . z . j$. Geol, and Geophys, $\mathbf{5}(5), 746-777$.

Swithinbank, C.W.M. 1973. Satellite view of McMurdo Sound, Antarctica. Prolar Rec., 16 105), 851-854.

Swithinbank, C. W. M., D. G. Darby and D. F. Wohlschlag. 1961 Faunal remains on an Antarctic icc shcll. Science, $\mathbf{1 3 3}(3455), 764-766$.

The accuracy of references in the text and in this list is the responsibility of the authors, to whom queries should be addressed. 